\title{
¿MADRE BONDADOSA O CRUEL MADRASTRA? IMAGEN NACIONAL Y CARICATURAS EN LA CULTURA VISUAL DE CUBA (1868-1878)
}

\author{
Kind Mother or Cruel Stepmother? National Imagen and \\ Caricatures in Visual Culture of Cuba (1868-1878)
}

\author{
Ainhoa Gilarranz \\ gilarranz.ainhoa@gmail.com \\ Universidad Autónoma de Madrid. España
}

Fecha de recepción: 12/06/2017

Fecha de aceptación: 30/01/2018

RESUMEN: A lo largo del siglo XIX, las mejoras técnicas en el mundo de la imprenta permitieron introducir asiduamente grabados, ilustraciones y caricaturas entre sus publicaciones. Los dibujantes satíricos se hacían eco de los acontecimientos que se debatían entre la sociedad y los representaban mediante su código humorístico en las páginas de prensa. La personificación de las naciones en alegorías, principalmente femeninas, se popularizó entre los caricaturistas proyectando imaginarios nacionales con unas características muy concretas. En los momentos de mayor conflicto social y político estas representaciones nacionales brotaban difundiendo ideales, opiniones y corrientes de pensamiento que llegaban a la población. Uno de esos acontecimientos fue la Guerra de los diez años (1868-1878) entre Cuba y España, el primero de los conflictos por la independencia que enfrentó a la colonia con la metrópolis. Mediante el estudio de fuentes iconográficas, principalmente las ilustraciones de Víctor Patricio de Landaluze en la publicación españolista Juan Palomo, se profundiza en la construcción del imaginario nacional tanto de España como de Cuba durante el conflicto, en el papel de la otredad en la fabricación de estas representaciones y su consolidación en otros productos: literatura y objetos cotidianos, con la intención de analizar la contienda desde su dimensión cultural.

Palabras clave: Estudios culturales; nación; imaginario; caricatura.

ABSTRACT: Techniques improvement in the printing world allowed the publication of illustrations and caricatures more frequently in the nineteenth century. The satiric draftsman illustrated the main debates of the society into the journals. The personifications of nations was popularized among caricaturists, especially with feminine allegories. Their pictures created national imaginaries with 
specific features. This national representations grew up and spread ideals, opinions and intellectual currents about the critical points of social and political dispute. One of this moment was Ten Years' War (1868-1878), the first independence conflict between Cuba and Spain. The aim of this paper is look into the construction of national imaginaries analyzing visual sources like Víctor Patricio de Landaluze's caricatures in Juan Palomo journal. Analysis of «the otherness» concept in the building of this representations and its consolidation in other products -literature or diary objects- is an important area into this research. Finally, the main point is to know how the political and warlike confrontation reached other dimensions such as the cultural battle.

Keywords: Cultural studies; nation; imaginary; caricature.

SUMARIO: 1. Imaginarios y caricaturas en el análisis histórico. 2. El costumbrismo cubano y la figura de Landaluze. 3. Las españas de Lanzaluze. 4. Imaginarios opuestos de una misma nación. 5. La consolidación de un imaginario. 6. Conclusiones. 7. Bibliografía.

\section{IMAGINARIOS Y CARICATURAS EN EL ANÁLISIS HISTÓRICO}

Uno de los objetivos principales de la historia cultural, corriente historiográfica desarrollada aproximadamente desde la década de los 80, es el estudio de la comunicación mediante dos elementos fundamentales: el texto y la imagen (Serna, Pons, 2005 pp. 5-14). Estos ingredientes comunicativos se incorporan en una sociabilización en la que varios factores forman parte de la ecuación: el emisor, el mensaje y el receptor que configuran un lenguaje propio, con sus símbolos y sus códigos convertido en uno de los temas esenciales de los estudios culturales en historia contemporánea. Gracias al giro cultural de las últimas décadas del siglo pasado, se inició un debate sobre la imagen como testimonio histórico que pasó a ser considerado un vestigio del pasado englobado en la categoría de material visual, entendida como todos aquellos objetos que hoy en día consideramos arte junto con otros construidos por el hombre y que son aprehendidos visualmente (Gaskell, 1993, pp. 209-215; 1998, pp. 99-100).

Entre las primeras investigaciones en historia contemporánea protagonizadas por las fuentes iconográficas destacó el análisis de los imaginarios nacionales como principal objeto de estudio. La construcción de la representación visual de Francia fue uno de los más fructíferos con trabajos dedicados a Marianne y a la simbología nacional desarrollada durante la Revolución francesa ${ }^{1}$. En el caso español, las primeras aproximaciones llegaron de la mano de los historiadores del arte; posteriormente se introdujo en el área de historia contemporánea con ensayos en los que la

${ }^{1}$ Pueden destacarse las obras: Landes, J. B. (1988) Women and the public sphere in the age of the French Revolution. London: Cornell University Press; Landes, J. B. (2003). Visualizing the Nation: Gender, Representation, and Revolution in Eighteenth Century France. London: Cornell University Press; Orobon M. A. (2005). Marianne y España: la identidad nacional en la Primera república española. Historia y política: Ideas, procesos y movimientos sociales, (13), pp. 79-98; Starobinski, J. (1988). 1789, los emblemas de la razón. Madrid: Taurus. 
construcción del imaginario nacional se analizaba a través de los discursos intelectuales desprendidos de las esferas culturales de la época². Muchas representaciones se personificaban mediante figuras femeninas a través de estampas, litografías o grabados. Con los avances en la industria de la imprenta, los ritmos se acortaron y era más sencillo publicar grandes ilustraciones en el interior de las cabeceras periodísticas. Junto a dibujos informativos se colaron las caricaturas; imágenes humorísticas que alcanzaron sus altas cotas de popularidad a partir de la segunda mitad del siglo XIX.

Con estos antecedentes, se plantea el análisis de los discursos culturales establecidos entre España y Cuba en el momento en el que estalla La Gloriosa y el conflicto armado en la isla caribeña conocido como la Guerra de los diez años (1868$1878)^{3}$. Durante este periodo histórico, el Caribe y el Golfo de México se convirtieron en un importante escenario geopolítico para la España del XIX; sus acciones sobre el territorio se dirigían a mantener su control total sobre la zona. Ahora bien, esto no fue fácil, Estados Unidos con sus intentos de anexionarse a las colonias antillanas dificultó la tarea al gobierno español, que tras las presiones diplomáticas de la administración norteamericana, decidió adoptar una actitud defensiva. El clima favorable entre la clase criolla a una anexión con EE. UU. llevó a que el gobierno español probara una aproximación entre la élite cubana y el régimen isabelino. Sus intentos se interrumpieron con la llegada de La Gloriosa; apenas un mes después de la revolución aparecieron los movimientos independentistas en Cuba y Puerto Rico. La sublevación puertorriqueña fue controlada rápidamente, todo lo contrario que en Cuba en la que se abrió una fuerte vía independentista; así comenzó la Guerra de los Díez años y el principio del fin de la época colonial hispana.

La batalla armamentística se expandió hacia un conflicto ideológico-cultural potenciado desde las principales cabeceras periodísticas. Las publicaciones más populares entre las élites sociales de Cuba eran dirigidas por conocidas personalidades del bando españolista. El objetivo de indagar en la formación de los imaginarios nacionales generados a partir de 1868 nos lleva al análisis en profundidad de

2 En este aspecto deben mencionarse las monografías de Álvarez Junco, J. (2001). Mater Dolorosa: la idea de España en el siglo XIX. Madrid: Taurus; Pérez Vejo, T. (2015). España imaginada: historia de la invención de una nación. Barcelona: Galaxia Gutenberg; Reyero Hermosilla, C. (2010). Alegoría, nación y libertad: el Olimpo constitucional de 1812. Madrid: Siglo XXI.

${ }^{3}$ Por citar algunos ejemplos de la producción historiográfica sobre esta contienda véanse: Corvea Álvarez, D. (2002). Las guerras contra España y la administración civil, mambisa en el centro oriental de Cuba (1868-1878 y 1895-1898). Las Palmas de Gran Canaria: Benchomo, 2002; Domingo Acebrón, M. D. (2010). Estados Unidos y su posición en la Guerra de Independencia de Cuba, 1868-1878: el reconocimiento de beligerancia. Boletín de la Real Academia de Extremadura de las Letras y las Artes, 18, pp. 413-428; Moro Barreñada, J. M. (2008). La guerra de los Díez Años 1868-1878). En Girón Garrote, J. (Ed.), Un cambio de siglo 1898: España, Cuba, Puerto Rico, Filipinas y Estados Unidos (pp. 49-56) Oviedo: Universidad de Oviedo; Roldán de Montaud, I. (2003). La política española en Cuba: una década de cambios (1876-1886), Ayer, 52, pp. 175-203. 
las caricaturas publicadas en la revista cubana Juan Palomo e ilustradas por Víctor Patricio de Landaluze. La situación en la perla antillana era descrita tanto desde las revistas isleñas como desde las españolas; por consiguiente, se ha considerado necesario realizar una comparativa entre las figuras alegóricas de la nación representadas en la prensa cubana y en las publicadas en la cabecera madrileña Gil Blas, o en la catalana La Flaca. Estas dos cabeceras joco-serias alcanzaron altas cotas de popularidad y de originalidad gracias a las litografías y cromolitografías que publicaban entre sus páginas (Sánchez Vigil, 2008, pp. 59-73).

El uso de las imágenes como fuente histórica tiene unas problemáticas vinculadas a la metodología de análisis. El documento iconográfico, además de los valores artísticos que posee, también tiene una proyección social y política que debe atenderse; sobre todo si el trabajo de estudio se enmarca en la historia cultural y la cultura visual. Otro valor añadido en las fuentes primarias estudiadas ha sido su carácter satírico que compone unos códigos comunicativos propios. Se puede caer en el error de «pretender que el humor funcione del mismo modo y de la misma manera en todas las sociedades y a lo largo del tiempo» (Gómez, 2010, p. 43) y por ello, se debe ser muy cuidadoso en la traducción del mensaje humorístico de las ilustraciones. Peter Berger, sociólogo y autor de Risa redentora. La dimensión cómica de la experiencia humana, indica que el humor es algo universal, si bien, lo que hace que algo se considere gracioso cambia según la sociedad y la época en la que nos encontremos. Este razonamiento nos lleva a la necesidad de comprender e incluir la comicidad en el análisis del vínculo histórico entre las esferas sociales y los acontecimientos, interactuaciones sociales en las que el humor brota de forma breve pero frecuente (Berger, 1999, pp. 120-123). En definitiva, el lenguaje humorístico debe ser analizado para comprender el mensaje icónico al completo. De esta manera, a la hora de adentrarse en el análisis de las caricaturas se ha tenido presente su código de lectura, diferente tanto al de otras expresiones artísticas: el mencionado género costumbrista u otros materiales visuales.

También se presentaban dificultades conceptuales vinculadas a lo entendido por imaginarios y representaciones en este estudio del caso. Ambos conceptos son muy flexibles y permiten muchas interpretaciones. Entre muchas de las dimensiones que abarca el término imaginario es interesante observar su dimensión hermenéutica; aquella que nos permite analizar la otredad, de modo que los imaginarios se convierten en esquemas de significado gracias a los cuales comprendemos la realidad que nos rodea (Randazzo. 2012, pp. 83-84). En resumidas cuentas, la manera en la que la sociedad organiza las representaciones dadas a sí misma (Pérez Vejo, 2005, p. 1120) ${ }^{4}$. Una variante de esta línea de pensamiento aparece vinculado al elemento icónico: «...Un imaginario tiene una enorme eficacia puesto que se sirve para homogeneizar mensajes y normalizar valores sociales que, a partir de ese

${ }^{4}$ Una definición proveniente de Baczko, B. (1984). Les imaginaires sociaux. Memoires et espoirs collectifs. Paris: Payot, citado en el estudio de Tomás Pérez Vejo. 
momento, aparecen como naturales y cotidiano.» (Andreo, 2011, pp. 37-66). Bajo esta misma idea Tomás Pérez Vejo, experto en el estudio de fuentes iconográficas, define los imaginarios colectivos como: «...una forma de ver el mundo, generalmente, a diferencia de la ideología, ni explícita, ni ordenada que mediatiza la manera en que una sociedad se imagina a sí misma y al mundo que la rodea y que se plasma en una sucesión de imágenes mentales más que en discursos articulados» (2012, p. 27). Bajo estas dos descripciones se maneja lo comprendido como imaginario en estas páginas, una interpretación utilizada en estudios como Imágenes e imaginarios nacionales en el ultramar español o América en el imaginario europeo o en la monografía colectiva Relatos de nación. La construcción de las identidades nacionales en el mundo hispánico ${ }^{5}$. En cuanto al concepto representaciones está especialmente ligado a la perspectiva de la historia cultural. Desde 1983 con la aparición del primer ejemplar de Representations, revista científica de la universidad de California, centrada en el estudio de las «dimensiones simbólicas de la practica social y las dimensiones sociales de la práctica artística» (Guzmán Vázquez, 2013, p. 18), seguida de grandes monografías y artículos especializados como los elaborados por Robert Chartier ${ }^{6}$. A este respecto, la representación se fusiona con el imaginario en los estudios culturales, y se comprende como:

Las diferentes formas a través de las cuales las comunidades, partiendo de sus diferencias sociales y culturales, perciben y comprenden su sociedad y su propia historia (...) nos faculta para pensar de manera más compleja y dinámica las relaciones entre los sistemas de percepción y de juicio y las fronteras que atraviesan el mundo social (Chartier, 1992, pp. 1-4).

La ecuación formada por los términos nación, imaginario y representación son clave para el objeto de estudio que aquí se presenta. La nación comprendida desde su dimensión cultural como una invención colectiva e histórica a partir de mitos, costumbres o lenguas construye un discurso coherente a través del que se podía reconocer el alma nacional (Reyero, 2009, p. 1197). El relato de la nación conformado por canciones o literatura se alimentó potencialmente en el siglo XIX de elementos

${ }^{5}$ Ambas obras publican estudios especializados en el estudio de imaginarios americanos mediante el análisis de fuentes iconográficas: Rojas Mix, M. (2005). El imaginario nacional latinoamericano. En Colom González, F. (Ed.), Relatos de nación. La construcción de las identidades nacionales en el mundo hispánico (pp. 1155-1175). Madrid: Iberoamericana; Lapique Becali, Z. (1999). Los sucesos de la historia de España y Cuba en las etiquetas de los cigarrillos y habanos cubanos. Naranjo, C. y Serrano, C. (Ed.), Imágenes e imaginarios nacionales en el ultramar español (pp. 103-116). Madrid: CSIC-Casa de Velázquez. 1999.

${ }^{6}$ Una idea principalmente desarrollada en Chartier, R. (1991). El mundo como representación. Historia Social, 10, pp. 163-176 y Chartier, R. (1996). El mundo como representación. Estudios sobre historia cultural. Barcelona: Gedisa. 
visuales. Dicho material icónico permitía a la sociedad comprender y ordenar por categorías el mundo que les rodeaba, y por otro lado, potenciaba la captación del mensaje a causa del lenguaje emotivo característico de este tipo de fuentes (Pérez Vejo, 2009, p. 1142). Es por ello, que la historia de las emociones también se encuentra presente en el análisis de las fuentes iconográficas presentadas. Una corriente historiográfica novedosa sobre la que Juan Manuel Zaragoza advertía una ausencia de un marco analítico riguroso y de una definición adecuada para su objeto de estudio (2013, pp. 1-2). Sin espacio suficiente para abordar en profundidad este aspecto, en el análisis desarrollado se atisba algún elemento analítico procedente de esta vertiente histórica por su importancia en el estudio de los imaginarios nacionales. La nación es una codiciosa institución: económica, física y emocionalmente en palabras de Joan B. Landes (2003, pp. 2-3). Los valores emocionales con lo que se representaban las alegorías nacionales eran impuestos por sus dibujantes, alejados de cualquier tipo de irracionalidad. Los ilustradores potenciaban una emoción para cada personificación nacional, escogían un sentimiento determinado para un propósito concreto dando lugar a las alegorías político-emotivas.

\section{EL COSTUMBRISMO CUBANO Y LA FIGURA DE LANDALUZE}

Una vez establecidos los objetivos del estudio, hay que adentrarse en la figura del pintor bilbaíno Víctor Patricio de Landaluze, no sin antes atender brevemente a la dimensión artística en la que se inició: el costumbrismo, una corriente cultural desarrollada durante el Romanticismo que partió de un conjunto de productos literarios y artísticos en los que se describían los ambientes y los tipos de la sociedad (Ayala, 1993, pp. 10-33). Las estampas y litografías costumbristas que aparecieron en Cuba a principio del siglo XIX difundieron ese interés hacia lo exótico y la fijación por los temas locales tan interesantes para los viajeros europeos como Mialhe, Garneray o Laplante (De Juan, 1983, p. 43). El paisaje geográfico y social de la isla fueron las principales temáticas de estas estampas, consecuencia del pintoresquismo y las vistas panorámicas que se habían popularizado en territorio europeo (Zárate Martín, 1992, pp. 41-66; Alaminos López, 1999, p. 16). De la primera mitad de siglo son: Habana. Vista del puerto y ciudad de Louis Le Breton, Vista general de la Habana de Hippolite-Jean-Baptiste Garneray y Vista del puerto de la Habana de Vicente Urrabieta que transmitía ese interés por la geografía y la topografía que comenzaron de popularizarse a finales del XVIII.

Los talleres litográficos llegaron a la isla a partir de 1830 difundiendo imágenes costumbristas tanto en la prensa de la época como en otros objetos populares como las conocidas marquillas cigarreras. El oficialismo pictórico llegaría con la fundación de la Academia de San Alejandro en 1818. Su producción artística, centrada en la estética europeizante y académica que primaba el gusto hacia el neoclasicismo, se 
distanciaba de las obras populares de corte costumbrista (Cabrera Salort, 2010, p. 96). De este modo, la cultura visual cubana contó por un lado con obras de estilo clasicista de la mano de Juan Bautista Vermay, director de la primera academia de bellas artes cubana; y otras de valor social e interés por los localismos focalizadas especialmente al trabajo del pintor bilbaíno Víctor Patricio de Landaluze. llustrador y caricaturista reconocido en el mundo del arte y considerado como «...el documentalista más vivaz de ciertas realidades sociales de la Cuba de su época...» (De Juan, 1983, p. 41).

Víctor de Landaluze nació en Bilbao el 6 de marzo de 1828 y con apenas veinte años llegó a la perla antillana. Se instaló en Cárdenas, lo que le llevó a ser testigo del desembargo del general Narciso López y de la muerte del lancero Feliciano Carrasco; acontecimiento que según algunos investigadores fue vital para posicionarse desde entonces contra todo movimiento revolucionario en la isla (López, 1998, pp. 9-11). Aunque destacó por su pintura de costumbres, a partir de 1857 desarrolló su perfil de caricaturista y fue en Juan Palomo donde sus ilustraciones políticas alcanzaron altos grados de popularidad bajo el contexto del enfrentamiento independentista.

En los años en los que Landaluze llegó a Cuba, el costumbrismo gozaba de uno de sus periodos más dorados gracias a publicaciones como El papel periódico de la Havana o la Colección de artículos satíricos y de costumbres. En este sentido era lógico que una de las primeras obras del pintor bilbaíno a su llegada fuera Los cubanos pintados por sí mismos. Colección ilustrada publicada en 1852 que mantenía la tradición de publicaciones similares que se habían popularizado por Europa una década antes: Les français peints par eux-mêmes (1840-1842) o Los españoles pintados por sí mismos (1843-1844). Los artículos de costumbres cumplían una doble función: por un lado, escenificaban lo que era considerado propio de la sociedad cubana, lo exteriorizaban y creaban una imagen de Cuba, al mismo tiempo que estimulaban la aparición de una conciencia nacional común. Por otro lado, en esa reconstrucción de la sociedad isleña se incluía una crítica a los vicios de la sociedad y de esos juicios de valor se nutrieron muchos de los contrarios a la independencia, como el propio Landaluze, para atacar el movimiento revolucionario. Sus primeros ensayos pictóricos aparecieron en publicaciones defensoras del integrismo peninsular, La Charanga, EI Moro Muza y Don Junipero, dirigidos todos ellos por Juan Martínez Villergas.

La pintura de costumbres de Landaluze se llenó de color y vitalidad. Sus lienzos de género eran humorísticos, destinados a un tipo concreto de público: la élite europea asentada en la perla antillana. Así, entre los personajes que forman parte de su obra pictórica destacó el esclavo doméstico de la urbe (Rodríguez, 1998, pp. 85-87). Sus ilustraciones están llenas de despreocupación y festejo hasta conseguir que quién visualizase la imagen olvidara que en ella se representaba a una persona en régimen de trabajo forzado. Este espíritu de divertimento caracterizó

7 Ilustró una escena sobre este acontecimiento que puede verse en la Biblioteca Digital Hispánica: <http://bdh-rd.bne.es/viewer.vm?id=0000026046>. 
su obra satírica mezclada con su mensaje político a favor de la patria española. La animadversión ante cualquier movimiento independentista quedó reflejada en sus litografías en las que ridiculizaba y caricaturizaba a los principales líderes mambises (Domingo Acebrón, 1993, pp. 31-40).

\section{LAS ESPAÑAS DE LANZALUZE}

Juan Palomo gozó de una corta vida, pero aguantó más que la mayoría de sus coetáneas. Desde su primer ejemplar, publicado en noviembre de 1869, incorporó la caricatura entre sus páginas centrales y dejó clara su línea editorial: «JUAN PALOMo, con la risa en los labios y la hiel en el corazón, viene á pelear en pró de la santa cáusa [sic] nacional (...) Su programa es bien sencillo. Liberal en principios hasta la pared de enfrente, y en Cuba al lado de la Autoridad...» (Juan Palomo, n.ㅇ 1, 1869).

Aquello que se defendía en los artículos: la protección a la patria, la captura de los insurrectos, la continuidad colonial, etc. era traducido pictóricamente por Víctor Patricio de Landaluze en cada uno de los ejemplares. Los líderes independentistas eran satirizados, transformados en bestias o etiquetados como ignorantes o alcohólicos. Sus ilustraciones presentaban la actualidad a golpe de humor y entre sus protagonistas también aparecieron las alegorías nacionales. El pintor bilbaíno fue reconstruyendo un imaginario nacional basado en la iconografía proveniente de la península, pero con un mensaje muy distinto. Mientras que en España la prensa joco-seria recayó en las manos de los grupos opuestos al colonialismo, principalmente los republicanos, en Cuba ocurrió todo lo contrario y eso se reflejó en el uso de la representación de España en uno y otro lado del Atlántico.

Un factor esencial dentro de toda comunicación es la comprensión del mensaje por parte de sus receptores, eso lo sabían los caricaturistas del XIX y por ello Landaluze utilizó los mismos símbolos con los que España era reconocida: la bandera, el león, el escudo nacional, los colores, etc., y los mismos modelos: la matrona, la maja y llegados a la fecha de 1873, la republicana. Sin embargo, el mensaje final era completamente diferente; en la península la prensa satírica llenaba sus páginas con una España demacrada: físicamente descuidada, en la extrema delgadez, de rasgos afilados y entristecidos. En Cuba, la nación española era una mujer esbelta, hermosa y sana que no temía enfrentarse a sus enemigos. La inclinación de unir la imagen de la nación a la decrepitud fue una característica de las caricaturas peninsulares. Esta alegoría se asentó y popularizó de tal manera que formó parte del sello editorial de algunas publicaciones; La Flaca, revista joco-seria catalana, decoró su cabecera con una España huesuda acompañada del león nacional en similares condiciones que su dueña. La mayoría de la prensa satírica de corte liberal se unió a esta tendencia pudiendo encontrar similares representaciones en: Gil Blas, La Carcajada, El Motín, El Guirigay del 69, El Guirigay del 70, etc. (vid. Ilustración 1). 
GIL BLAS.

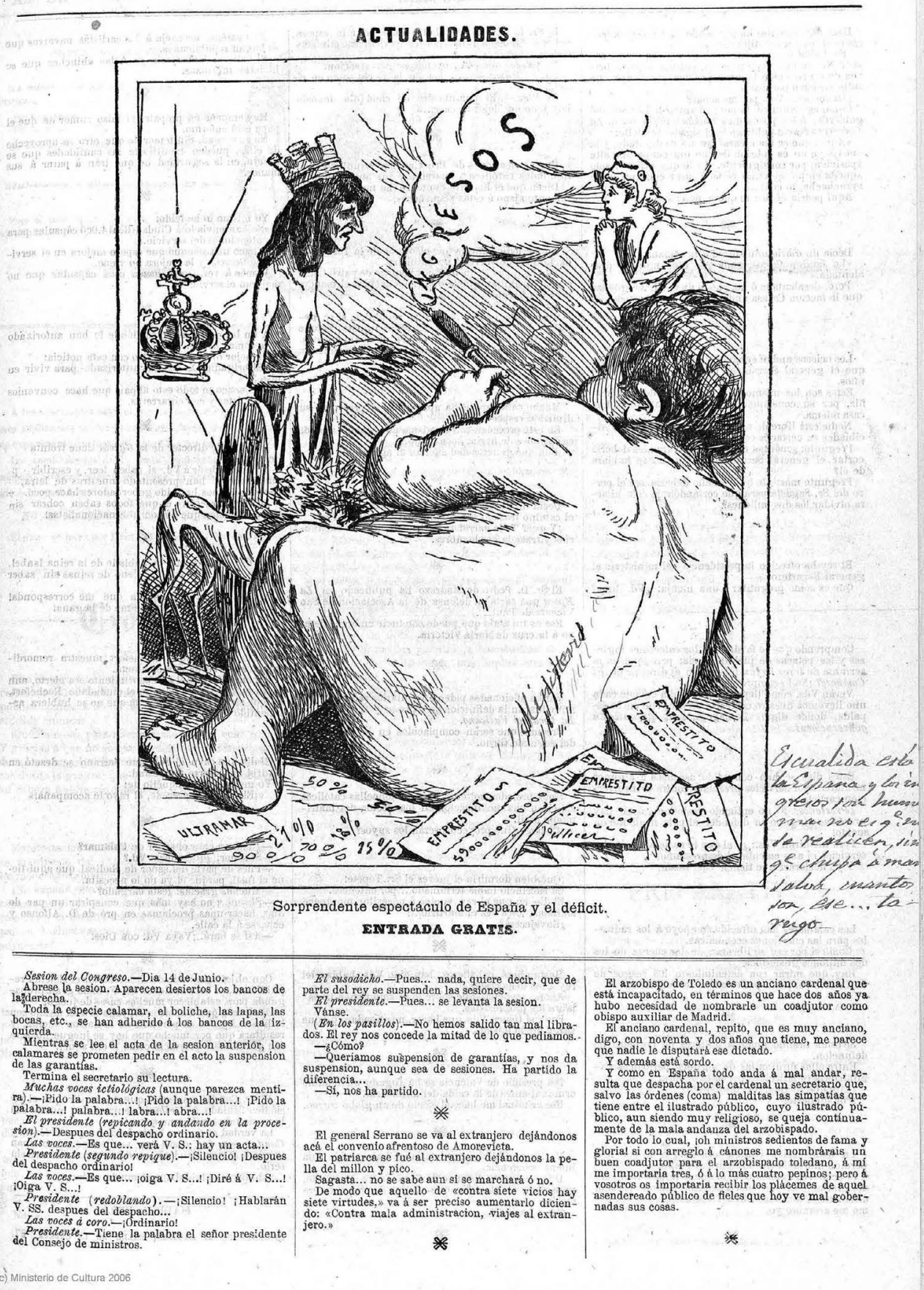

Ilustración 1. Alegoría de la España demacrada publicada en Gil Blas no24 (16 junio 1872). Fuente: ARCA <http:// www.bnc.cat/digital/arca/>. 
Entretanto los ilustradores satíricos en Cuba modifican la alegoría proveniente de la península y la adaptan a sus propios intereses. Así aparecieron en las páginas españolistas dos representaciones para la nación que no se encontraban entre las ilustraciones peninsulares del XIX. La primera de ellas conformaba una alegoría centrada en la fortaleza de España: la nación guerrera; y la segunda, reconstruía una imagen ya conocida entre la población pero que en la perla de las Antillas fue reformulada: la madre patria. La España guerrera apareció en la prensa antiseparatista como medio de representar la fortaleza de la nación frente a los conflictos que se le presentaba, tanto dentro como fuera de la isla. No sólo se modificó su vestuario habitual, sino que era retratada con un carácter luchador y activo, opuesto completamente al pasivo y doblegado con el que se ilustraba en la península. La figura combatiente se mantuvo constante en toda la existencia de Juan Palomo: en abril de 1870 luchaba contra la insurrección cubana, en julio de 1872 se enfrentaba al agresor de Amadeo I, en abril de 1873 desafiaba a la hidra; cuyas cabezas representaban el carlismo, la anarquía, el fanatismo religioso, el alfonsismo y la miseria (vid. Ilustración 2).

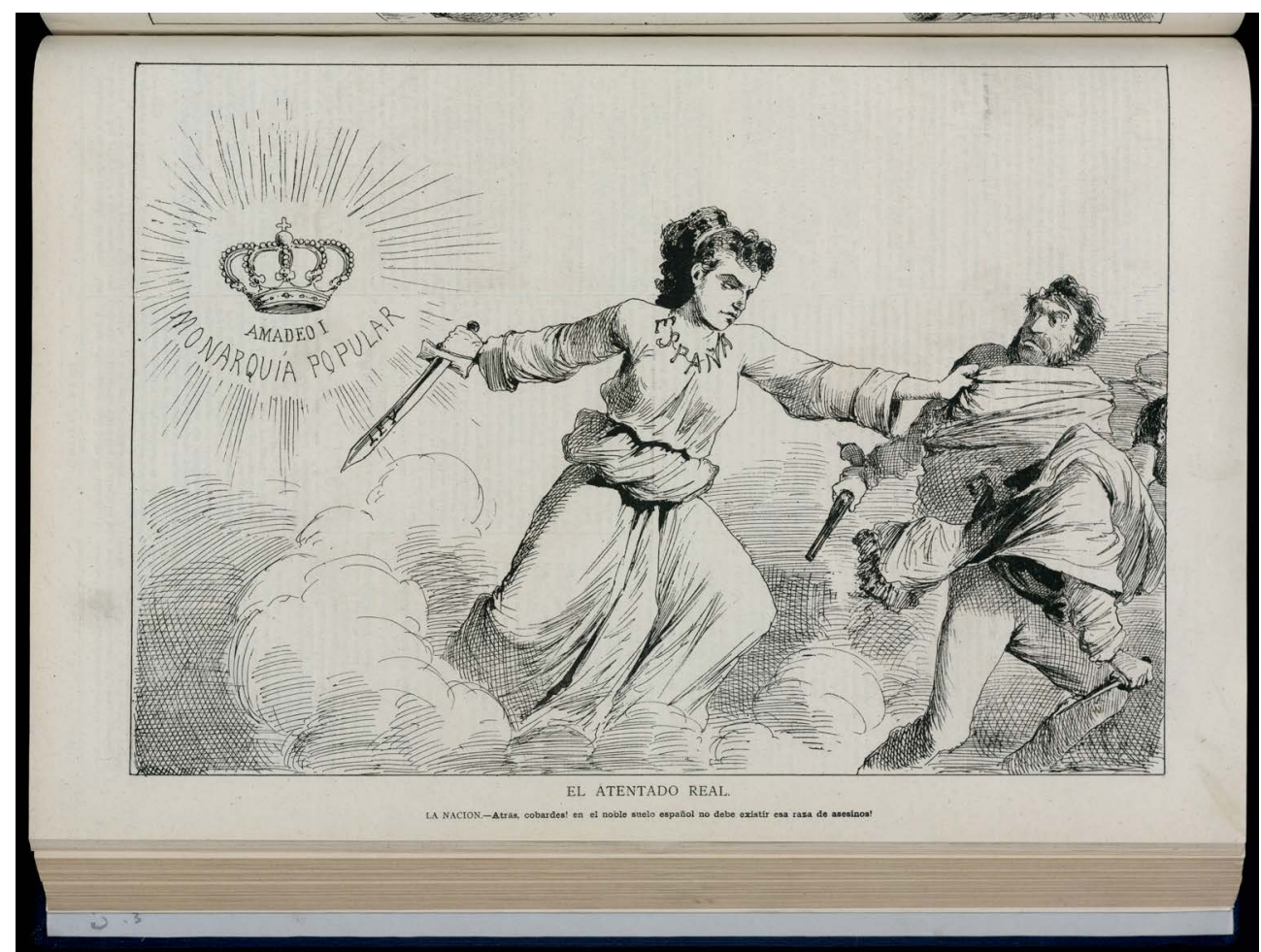

Ilustración 2. Alegoría de la España guerrera publicada en Juan Palomo n.o 30 (28 julio 1872). Fuente: Cuban Heritage Collection de la Universidad de Miami: <http://merrick.library.miami.edu/cdm/ search?collection=chc9998>. 
La madre patria fue la segunda alegoría más utilizada por Landaluze para representar a España, pero los cambios en su significado fueron notables. En las publicaciones peninsulares, España era una madre sufridora por la muerte de sus hijos; exteriorizando una línea editorial opuesta a las quintas, o desquiciada por las disputas entre los partidos políticos. En contraposición, el pintor bilbaíno ofrece otra postura maternal basada en una imagen cariñosa y paciente de la nación, esta representación era empleada principalmente en la relación entre la madre España con la hija Cuba. La nación española aconsejaba, protegía y cuidaba el territorio antillano, que era representado o bien como una figura infantil o una manceba en busca del consejo de su madre. A partir de esta alegoría se desligaba otra relacionada con Cuba; el mensaje quedaba claro: la isla siempre estará supeditada a la patria, sola no tiene nada que hacer y asombra la comparación de su representación con la ilustración de otras naciones dentro de Juan Palomo. Como reflejo de este hecho pueden observarse un conjunto de imágenes publicadas en el 1873 en las que se observa los diferentes vínculos entre la España respecto a Cuba o en relación con las naciones europeas. En marzo, Patricio de Landaluze decoraba la revista con una escena de complicidad entre Francia y la matrona española; "Yo he tenido la suerte de encontrar a un hombre que hará mi felicidad», indicaba la dama francesa que terminaba su diálogo con una recomendación a la maja española: «Un consejo antes de separarnos hermana. Cuida de no bailar con ninguna de aquellas groseras máscaras -señalando a un grupo de hombres que simbolizan la ignorancia, el comunismo y el fanatismo-. A mí me invitaron y por poco me cuesta la vida...». El pintor vasco representa a las naciones en un ambiente familiar entre iguales, similar al que se publica un mes después en la misma revista (vid. Ilustración 3).

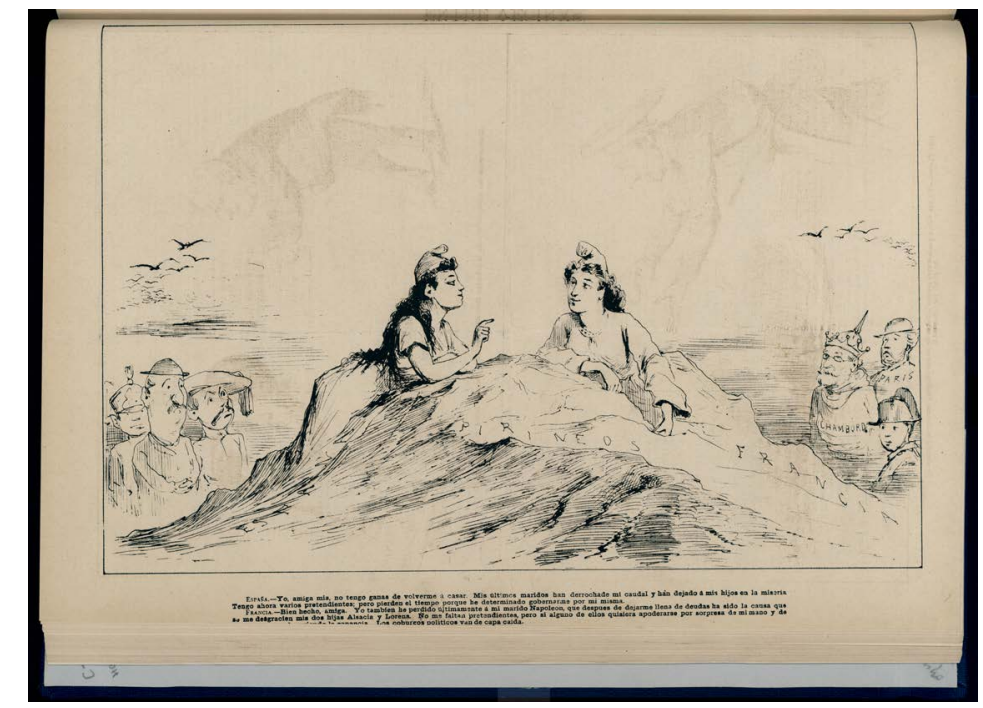

Ilustración 3. Alegorías de España y Francia publicada en Juan Palomo n.o 14 (6 abril 1873). Fuente: Cuban Heritage Collection de la Universidad de Miami: <http://merrick.library.miami.edu/cdm/search?collection=chc9998>. 
Los nexos parentales se mantienen en las litografías representadas por España y Cuba, pero quién da los consejos, y en ocasiones mandatos, es la madre hispana: «....niña, ven a lavarte la cara para que te presentes fresca y bonita delante de todos...» (Juan Palomo, n.o 33, 1873). La imagen que se difundía por la isla a través de estas publicaciones era la de Cuba vinculada familiarmente a España, en una relación de inferioridad con respecto a la alegoría española. Así, la perla antillana aparece como mujer sufridora siendo atacada por miembros del bando independentista y sólo es representada en actitud sosegada cuando es ilustrada junto a España. El modelo de nación en decrepitud y apática, que predominaba en la península, fue tomado por el caricaturista de Juan Palomo para adoptarlo a la alegoría de isla. La imponente imagen de mater dolorosa era inexistente en el territorio cubano. En cambio, si apareció la figura de la hija incauta y descuidada, que debe ser controlada por su propio bien, aunque ella misma esté en contra, un claro mensaje propagandístico favorable a la causa españolista (vid. Ilustración 4).

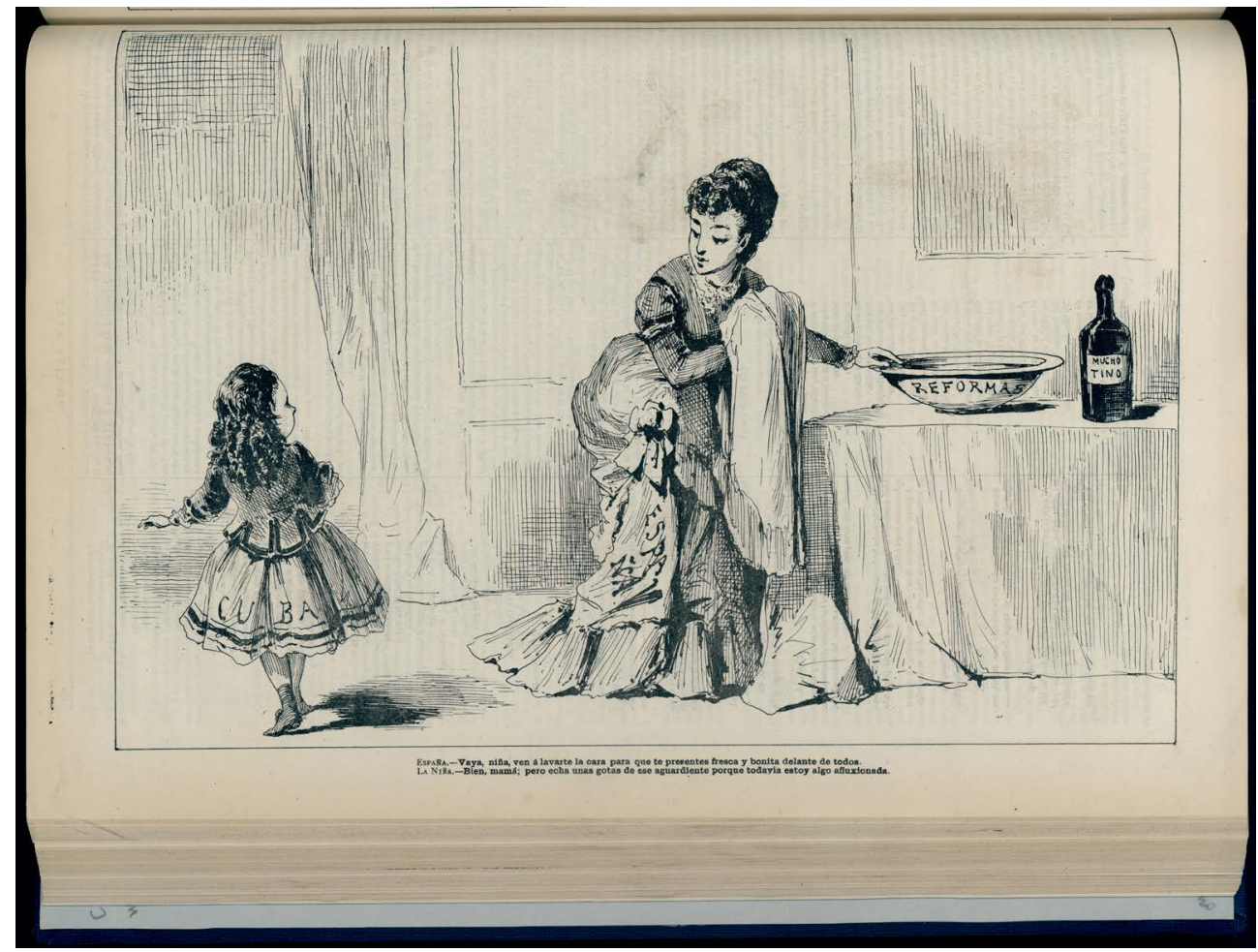

Ilustración 4. España maternal y Cuba infantilizada publicada en Juan Palomo n.o 33 (17 agosto 1873). Fuente: Cuban Heritage Collection de la Universidad de Miami: <http://merrick.library.miami.edu/cdm/ search?collection=chc9998>. 
Existió otra diferenciación entre las representaciones nacionales elaboradas entre la prensa española asentada en la Isla y las publicadas en España: la alegoría de Cuba. Si desde Juan Palomo la imagen de Cuba se representaba como una menor de edad, siempre acompañada de la alegoría de España en su rol de madre y protectora; la nación cubana era representada de manera muy distinta en las cabeceras peninsulares: mujer exuberante, de tez negra, fuerte de actitud activa, como ocurría en La Flaca del 16 de enero de 1873 en el que se pide la abolición de la esclavitud. Esta ilustración de Tomás Padró representa a Cuba como protagonista de la escena en el centro de la imagen, en una posición muy similar a la alegoría de la Libertad pintada por Eugene Delacroix; en esta ocasión, Cuba ondea una bandera española con la palabra libertad en vez de portar un estandarte francés. La alegoría cubana de la publicación catalana no tiene nada que ver con la ilustrada por Landaluze. La Cuba del pintor bilbaíno era representada al estilo europeo como una alegoría clásica, o bien como menor de edad con un vestuario a la moda burguesa que la alejaba de la representación mulata surgida en España. Esto se daba en parte porque el propio pintor vasco representaba a la mujer mulata en contextos de vulgaridad y agresividad que se instauraron en el imaginario colectivo, he aquí que su representación de Cuba debía alejarse por completo del estereotipo que él mismo había producido de la mujer cubana en sus ilustraciones costumbristas (Méndez Gómez, 2025, p. 154).

La representación de la nación en la Isla continuó con la tradición pictórica de la época en materia de género. El estudio de Salvador Méndez Gómez indica que en 1867 un 50\% de las viñetas publicadas en Don Junipero representaban personajes femeninos, dentro del cual sólo un $2 \%$ eran mujeres negras y un $0,84 \%$ mulatas por lo que no es de extrañar que la Cuba representada por Landaluze sea una mujer blanca, de rasgos occidentales sin atisbo de mestizaje (2015, p. 147). El rol representado era el del «ángel del hogar», popular entre las litografías de época, como puede observarse en las caricaturas en las que España educa a la Cuba infantilizada y cumple su papel de madre. Por otro lado, en la España guerrera sus gestos se masculinizan, su atuendo se aleja de la moda femenina de la época, sus facciones se endurecen como ocurre en "Hércules y la Hidra Lernea» (vid. Ilustración 5). En estos casos, España no se enfrenta a hombres, sino que sus enemigos son animalizados por lo que la superioridad femenina frente a masculina no se observa en ninguna de las caricaturas, como si ocurre en el caso contrario que puede observarse en la litografía de mayo de 1870 en la que un grupo de cabeceras periodísticas personificadas en varones lanzan flechas a Cuba atada en un poste (vid. Ilustración 6).

Por otra parte, se debe atender a la construcción iconográfica de la nación por parte del colectivo independentista. Una de las primeras alegorías de Cuba surge durante la guerra de los Díez Años, apareció en los billetes de 500 pesos emitidos 
por la Junta Central Republicana de Cuba y Puerto Rico a partir de $1869^{8}$. Los líderes sublevados no generaron un imaginario propio, sino que la iconografía y los símbolos eran similares a los provenientes del viejo continente, puede ser que como modo de legitimarse. No fueron los únicos, existen otros casos en la construcción de los estados-nación latinoamericanos: La Patria o la tumba de Hidalgo (1859) ilustrada por el Felipe Castro es uno de ellos. Esta obra pictórica representa a la nación mexicana a través de la imagen de una matrona clásica ataviada con un gorro frigio y cuyo atuendo completa los colores de la bandera mejicana -verde de la tela, blanco de su vestido y rojo del sombrero- y que en nada se la diferencia iconográficamente hablando con la Marianne francesa.

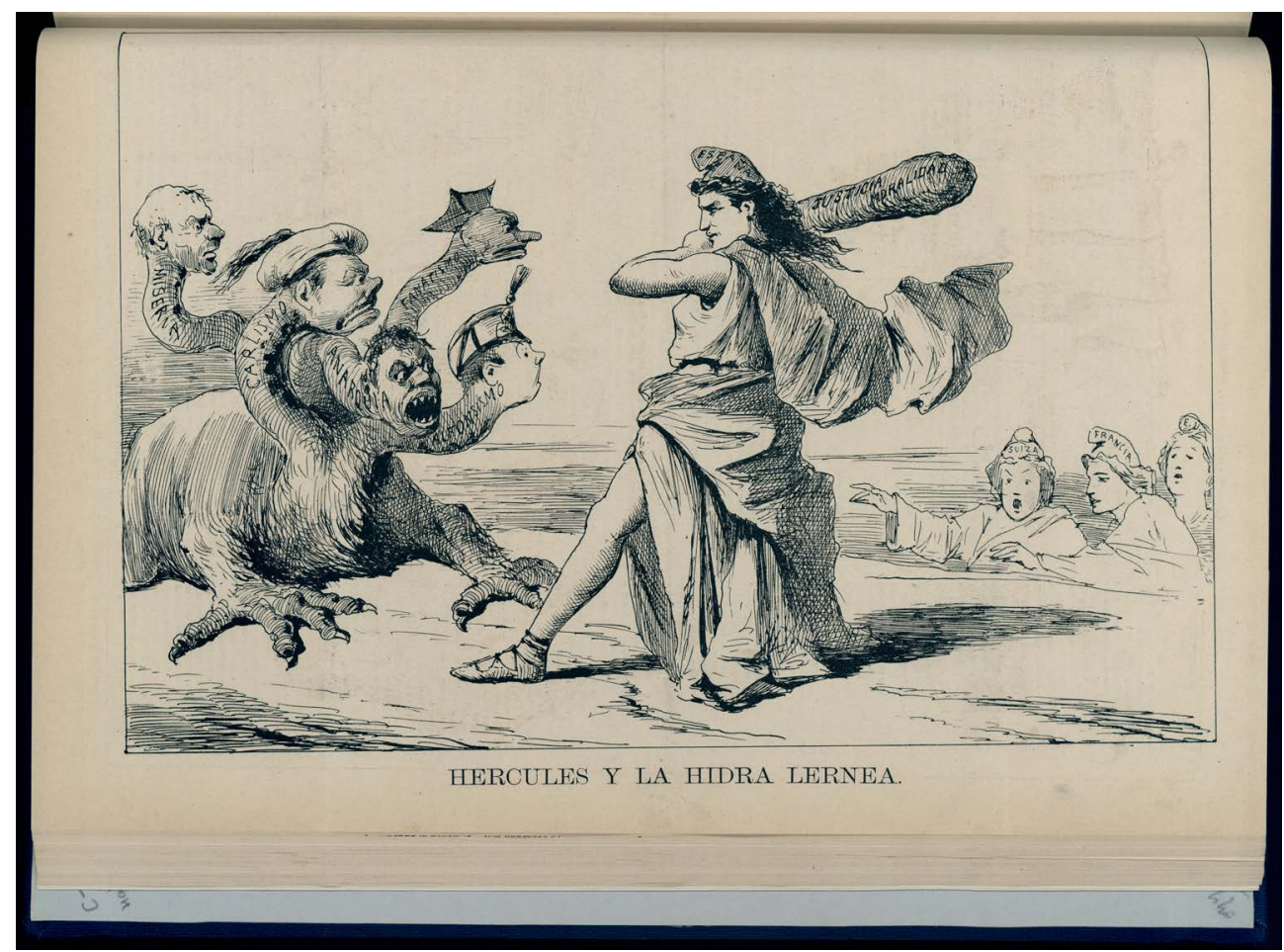

Ilustración 5. Alegoría de la España masculinizada publicada en Juan Palomo n.o 15 (13 abril 1873). Fuente: Cuban Heritage Collection de la Universidad de Miami: <http://merrick.library.miami.edu/cdm/ search?collection=chc9998>.

8 Puede contemplarse uno de estos billetes entre los fondos digitalizados del Museo Arqueológico Nacional. Inventario 2008/177/2. Recuperado el 09 de junio de 2017, de <https:// www.europeana.eu/portal/es/record/2022703/oai_euromuseos_mcu_es_euromuseos_ MAN_2008_177_2.html>. 


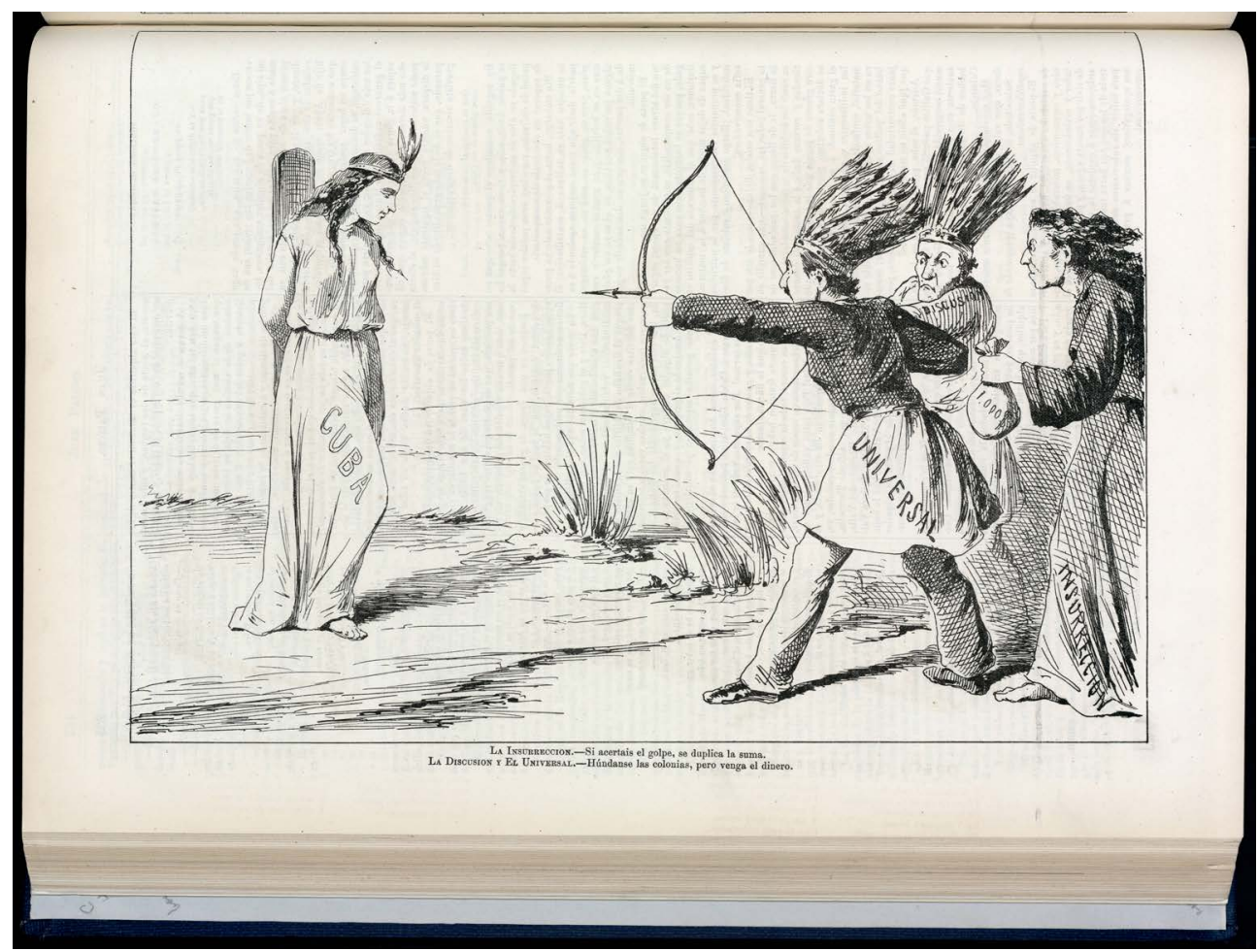

Ilustración 6. Alegoría de Cuba publicada en Juan Palomo n.o 30 (29 mayo 1870). Fuente: Cuban Heritage Collection de la Universidad de Miami: <http://merrick.library.miami.edu/cdm/search?collection=chc9998>.

El choque icónico para difundir un imaginario u otro queda retratado en los ejemplos presentados. Los ilustradores españoles de la península mantuvieron la iconografía de la tradición europea caracterizada por representar América como una mujer indígena ataviada con plumas (Gutierrez R, Gutiérrez Viñuales, R., 2006, p. 24). Un estilo iconográfico instaurado de manera oficial desde inicios del siglo XIX que se fue implantando en la reproducción ilustrada de los territorios colonizados. El grabado de Juan Antonio Salvador Carmona de finales del XVIII constituye otra ejemplificación de este estilo alegórico; el continente americano era personificado por una joven amazona con un tocado de plumas sobre la que sobrevuela una matrona española como símbolo de esa tutela de España sobre sus territorios coloniales ${ }^{9}$. En comparativa, esta alegoría no dista mucho visualmente de la personificación de Cuba elaborada en la prensa peninsular, como el caso de Tomás Padró en La Flaca, a pesar de que su mensaje es totalmente contrario: el grabado dieciochesco

${ }^{9}$ Salvador Carmona, J. A. // Museo de Bellas Artes de Granada (1770). Alegoría de América. Madrid. Recuperado el 09 de junio de 2017, de <http://ceres.mcu.es/pages/Main?idt=124595\& inventary $=1220 / 80 \&$ table=FMUS\&museum=MBAGR $>$. 
difunde una imagen de las colonias controladas por la metrópolis, y en el caso de la publicación catalana lo que se pide es la independencia de la perla antillana.

\section{IMAGINARIOS OPUESTOS DE UNA MISMA NACIÓN}

El imaginario nacional se altera a su llegada a la isla. Ante el enfrentamiento, que se inicia en 1868, los medios españolistas se blindan entorno a una alegoría renovada y vigorosa. Se eliminó todo atisbo de crítica proveniente de la península, en donde el imaginario progresista adquirió un espacio predominante en la prensa y dotó de heroísmo a las figuras del bando rebelde en Cuba (Lida, 2006, p. 77). La emotividad con la que España fue representada cambió y dotó a la nación de sentimientos positivos, que la alejaban del victimismo habitual con el que aparecía en las revistas peninsulares. Surgió una alegoría emotiva predominante: la España bondadosa, un estilo alegórico representado tanto iconográficamente como por medio de la palabra escrita:

...estréchense los lazos que nos unen mutuamente, forménse [sic] el espíritu nacional, hágase comprender á unos y otros en aquella apartada isla y á la sombra de la bandera española representan una de las mayores glorias del mundo moderno (...) y todo el que tenga una sola gota sangre castellana en las venas, reivindicará orgulloso su título de español y responderá con hidalguía y cariño al noble y amoroso llamamiento de la patria» (Anónimo, 1869, p. 15).

Por parte de los independentistas hubo respuesta ante esta imagen sana de la nación y la atacaron con el uso de modelos alegóricos y emotivos invertidos: «¿Qué ha sido España monárquica para la isla de Cuba sino una cruel madrastra? ¿Cuál la historia de la dominación española en las mal llamadas Colonias? Calvarios de mártires, série [sic] de criminales vejaciones, iniquidades sin límites, y sobre todo una negra ingratitud con que siempre la Metrópoli ha pagado la sumisión de sus colonias» (Anónimo, 1873, p. 4).

El imaginario trasladado a Cuba se completó con una nueva galería de salvadores patrióticos. Bajo el título de "Los héroes de la patria» publicaciones y estampas difundían los retratos de miembros del estamento militar español en la isla. Además de los publicados en Juan Palomo, otras revistas de similares características difundían las mismas ilustraciones; El Moro Muza elaboraba su propia colección y la publicaba con el nombre de "Los defensores de la integridad nacional». Junto a las personalidades del ejército español, tomaron protagonismo los militantes del cuerpo de voluntarios, defendidos con fiereza desde las revistas españolistas (vid. Ilustración 7). La sombra de crítica llegó por parte de los diputados del Congreso; Nicolás Salmerón, Díaz Quintero y Eduardo Benot quienes configuraron las voces 
críticas contra los voluntarios y su poder creciente en la perla antillana ${ }^{10}$. Así se expresaba el tercer presidente de la Primera República española durante una de las sesiones parlamentarias: «...la servil flaqueza, la indigna complacencia está en alabar la conducta baja, cobarde y brutal de los voluntarios de la Habana... $\rangle^{11}$.

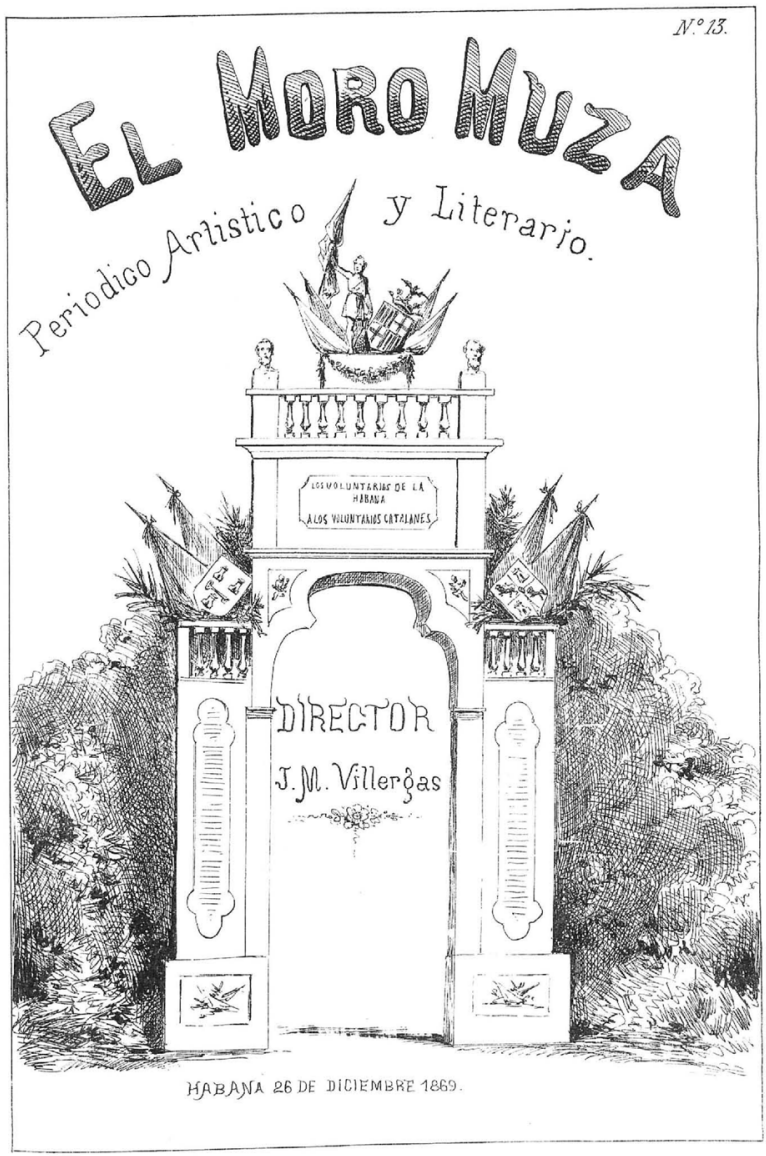

Arco de la calle de Mercaderes.

(1) Biblioteca Nacional de España

Ilustración 7. Arco en honor a los voluntarios de Cuba publicado en El Moro Muza n. 10 (5 de diciembre de 1869). Fuente: Hemeroteca de la Biblioteca Nacional de España. <http://hemerotecadigital.bne.es/details. vm?lang=es\&q=id:0004283112>.

10 Para conocer más sobre el papel de los voluntarios durante la guerra de los 10 años dirigirse a Casanovas, J. (1998). Bread or bullets!: urban labor and Spanish colonialism in Cuba, 1850-1898. Pittsburg: University of Pittsburg Press

11 Congreso de los diputados (1873) Diario de las sesiones de Cortes: Congreso de los Diputados: legislatura de 1872 á 1873, esta legislatura dio principio el domingo 15 de setiembre de 1872 y terminó el martes 11 de febrero de 1873. Madrid. Recuperado el 01 de mayo de 2017, de <http://www.congreso.es/est_sesiones/>. 
El enfrentado posicionamiento entre los dirigentes españoles en La Habana y las órdenes que llegaban desde la península se acrecentaban al ritmo que la contienda avanzaba. El protagonismo del cuerpo de voluntarios aumentó en la prensa isleña y su figura como héroes patrióticos se asentó en territorio cubano; e incluso llegaron a convertirse en mártires de la patria como ocurrió con Gonzalo Castañón, coronel de los voluntarios en La Habana y director de la publicación La Voz de Cuba, asesinado por seguidores de la causa independentista. Las festividades y los monumentos que se elaboraban en honor a los voluntarios eran anunciados dentro de las publicaciones españolistas, sin embargo en las peninsulares apenas se les mencionaba salvo cuando eran criticados desde el Congreso. El choque ideológico no pudo evitarse, y eso afectó a la prensa isleña; ante la incapacidad de controlarla, Madrid se posicionó en su contra e inició un ataque hacia ella en forma de censura y sanciones. Juan Palomo, entre otras revistas, no pudo eludir al Gobierno y tras una sanción de un mes de cierre, impuesta en abril de 1874, murió sin volver a publicar un ejemplar desde entonces ${ }^{12}$.

Lo que se estableció mediante las fuentes iconográficas fueron dos discursos nacionales basados en la otredad. Una construcción nacional en función de la diferenciación con el otro. Curiosamente, la iconografía utilizada era la misma, sin embargo, el imaginario era el opuesto. Mientras que la personalización de la nación española era similar tanto para los independentistas como para los españolistas, para la formación del imaginario era necesario el uso de valores, ideas y emociones adjudicadas a un concepto de nación $u$ a otro. Estos ingredientes afectaban a la vida política y social de los ciudadanos y los cohesionaban a su cuerpo social (Rojas Mix, 2005, pp. 1156-1157). De este modo, a lo largo de los diez años que duró el primer enfrentamiento independentista entre Cuba y España, la defensa de un ideal político se ilustró en alegorías nacionales entre las que se intercambiaban los códigos simbólicos y cuya similitud ideológica no conformaba una unidad en su representación visual. Por ejemplo, la alegoría de Cuba elaborada por el bando independentista se construía bajo una estética similar a la representación española del bando antiseparatista, ambas agrupaciones defendían un ideario contrario; mientras que, esa imagen visual de Cuba se alejaba por completo de la iconografía potenciada por los grupos republicanos que desde España apoyaban la autonomía de la isla.

Las representaciones nacionales latinoamericanas difieren en construcción respecto a las europeas en esta ocasión. Los estados latinoamericanos necesitaban un relato que los configurase como nación, se trataba de una necesidad política ya que sin esta no se conseguía la legitimidad con la que establecer el Estado moderno (Pérez Vejo, 2009, pp.1141). El discurso legitimador a través del código visual se conformó con una mirada hacia la cultura visual de sus antiguas metrópolis y se nutrió de los códigos iconográficos de la vieja Europa, en vez de centrarse en un pasado glorioso anterior a la colonización.

12 Archivo Histórico Nacional (1874). Suspensión de un mes impuesta al periódico Juan Palomo y cese de su director (4738 ULTRAMAR, Exp.4). 


\section{LA CONSOLIDACIÓN DE UN IMAGINARIO}

No debe pensarse que las personificaciones presentadas por Juan Palomo eran una singularidad de su ilustrador, el debate sobre Cuba y su representación no quedaron expuestos únicamente en la prensa. La guerra alegórica quedó latente en la publicación de panfletos como: Votos de un español (Madrid, 1869), Viva la integridad de la patria (Madrid, 1871), Tres cuestiones sobre la isla de Cuba: ¿de dónde venimos?, ¿dónde estamos?, ¿adónde vamos? (La Habana, 1876); que eran respondidos por textos anticoloniales: Votos de un cubano (Madrid, 1869), El verdadero patriotismo en la cuestión cubana (Londres, 1872), etc. Los españolistas hablaban de la «buena madre España», de la «Patria heroica, grande y respetada» o de la «patria más guerrera» ${ }^{13}$; mientras que los textos independentistas la etiquetaban de "despótica dominadora» o la increpaban: «sé por lo menos humana» escribía el patriota cubano Fermín Valdés Domínguez ante la negativa de otorgar la emancipación a la isla ${ }^{14}$.

El imaginario traspasó las páginas periodísticas y literarias para llegar a otro ambiente cultural: el teatro. El último acto de El patriotismo español y la insurrección de Cuba se escenificaban sobre las tablas de un escenario las figuras de Cuba y España junto al simbolismo de corte españolista:

Templo de la gloria. En primer término, España en figura de una hermosa matrona en trage [sic] de guerra con el escudo nacional y reclinada en un lecho de banderas y trofeos y otros atributos militares. Una bellísima joven que representa á la isla de Cuba, en trage [sic] indio, pero en la cual dominan los colores emblemáticos de España, se apoya en esta, la cual rodea con su brazo, maternalmente el cuerpo de la joven (Villa, 1871, p. 18).

13 Estos términos aparecen asiduamente en las siguientes obras: Aráiztequi, R. M. (1873). Votos de un español. Madrid: Imp. Manuel Minuesa; Ruiz y López de S.Román, F.M. (1872). Cuba y sus enemigos: defensa de los voluntarios de la isla de Cuba contra los ultrajes proferidos en las Cortes españolas en detrimento de su honra publicada en la prensa de la Cortey de Provincias. Madrid: Imp. Lázaro Maroto; Anónimo. (1869). Album vascongado: relación de los festejos públicos hechos por la ciudad de La Habana en los días 2,3 y 4 de junio de 1869, con ocasión de llegar a ella los tercios voluntarios enviados a combatir la insurrección de la isla por las... provincias de Alava, Guipúzcoa y Vizcaya. La Habana: Imp. J. M. Eleizegui.

14 Estos términos aparecen asiduamente en las siguientes obras: Donderis, E. (1876). La cuestión de Cuba. Nueva York: Imp. de E.H. Jones; Valdés Domínguez, F. (1873). Los voluntarios de la Habana en el acontecimiento de los estudiantes de medicina por uno de ellos condenado a seis años de presidio. Madrid: Imp. de Segundo Martínez. 
Las alegorías y símbolos que representaban a Cuba y a la nación española no se quedaron retenidas en las caricaturas políticas o en la prensa españolista, se difundieron a través de otros materiales visuales y objetos cotidianos. A mediados del siglo XIX, ya aparecían objetos diarios, como abanicos, que eran decorados con la personificación de estos territorios y en los que se inscribían lemas como: "La España y Cuba siempre» o "Cuba española » ${ }^{15}$. Pero sin duda, fueron las marquillas cigarreras cubanas, muy populares entre la población y de importante valor litográfico, las que ayudaron a difundir el imaginario nacional españolista a los ciudadanos de las Antillas durante la segunda mitad del XIX.

Desde las primeras décadas decimonónicas, las marquillas ofrecían bellas ilustraciones sobre diversos temas culturales y sociales, presentando un especial vínculo con la historia de España con el fomento de colecciones dedicadas a: regiones españolas, políticos peninsulares, uniformes militares de España, corridas de toros, etc. ${ }^{16}$. Un año antes del inicio de la guerra de los Díez Años, la marca cigarrera La Honradez elaboró una serie dedicada a los «Voluntarios de Cuba». Durante la contienda también aparecieron marquillas dedicadas a «las costumbres españolas» en las que se representaba la figura de España y La Habana apoyadas en sus respectivos escudos de armas. Las alegorías eran clásicas sin ningún apunte destacable con respecto a las representaciones habituales de España; sin embargo, destaca la ausencia de ilustraciones referentes a la figura de Cuba. A pesar de que el prestigio de estos cigarros se hallaba en su carácter cubano, hubo que esperar al desastre del 98 para que la figura de una Cuba sin vínculos con la madre hispana apareciese reflejada en estos objetos cotidianos ${ }^{17}$.

Se observa como el imaginario nacional, implantado por los españolistas, llegó a todos los elementos de la sociedad y se instauró en el día a día de los ciudadanos que visualizaban esas representaciones de España a través de los componentes culturales instaurados en la sociedad. Las alegorías que favorecían el vínculo entre la metrópolis y Cuba se transmitían desde diferentes medios: prensa, actividades culturales y elementos cotidianos. El imaginario que prevaleció en la sociedad fue aquel generado y expandido por quién tenía el poder en la sociedad, independiente de la autoridad política; en Cuba se difundían las representaciones favorables a los círculos coloniales de la isla, no la deseada por los líderes peninsulares.

15 Museo Nacional de Artes Decorativas (1855). Abanico plegable (n. inventario CE04960). Madrid.

${ }^{16}$ La Biblioteca Nacional de España tiene una amplio fondo digitalizado de marquillas cubanas que puede consultarse en: <http://www.bne.es/es/Catalogos/BibliotecaDigitalHispanica/Inicio/ index.html>.

17 Para saber más sobre la producción de las marquillas en la segunda mitad del siglo XIX dirigirse a: Núñez Jiménez, A. (1989). Marquillas cigarreras cubanas. Madrid: Tabapress; Fraunhar, A. (2008). Marquillas cigarreras cubanas: nation and desire un the nineteenth century. Hispanic Research Journal: Iberian and Latin American Studies, 9(5), pp. 458-478. 


\section{CONCLUSIONES}

A partir de la figura de Víctor Patricio de Landaluze y su obra pictórica se entrevé el proceso de elaboración de un imaginario nacional supeditado al mensaje que quería transmitir su creador. Las litografías de Juan Palomo se adentran en la producción cultural del periodo analizado y permiten comprender los distintos discursos de poder que se entremezclaron durante la guerra de los Díez Años; aquello que se defendía en la península no era lo mismo que se apoyaba desde la isla y ello quedaba reflejado en la distorsión de los modelos simbólicos e iconográficos con los que España era representada. Un imaginario expandido a todos los estamentos de la sociedad y que aparecía tanto en prensa, como en las obras dramáticas o en los objetos que guardaban los ciudadanos en sus bolsillos diariamente.

En cuanto a la figura de Landaluze, su fuerte oposición a la independencia de Cuba le trajo problemas en su carrera artística. Ha sido durante varias décadas olvidado en el mundo artístico a pesar de ser uno de los pintores costumbristas más brillantes de la segunda mitad del XIX (Domingo, 1993, p. 34). Sin embargo, a partir 1870 sus opiniones se suavizaron y con el cierre de Juan Palomo en 1874 no volvió dibujos satíricos hasta nueve años después, cuando colaboró en la cabecera Don Circunstancias con un lenguaje icónico mucho más moderado que en etapas anteriores (García Ronda, 1998, pp. 33-47).

Por otro lado, se ha observado la evolución de círculo emocional que rodea la alegoría nacional, en concreto la española. En el siglo XVIII la matrona hispana era representada de manera clásica, divina y fría...; un estilo que se observa en la Alegoría de España, obra anónima que forma parte de la Fundación Lázaro Galdiano, o en el lienzo de Corrado Giaquinto, España rinde homenaje a la Religión y a la Fe. Las ilustraciones de Víctor Patricio de Landaluze reflejaban una España muy diferente, más humanizada, y entre el abanico sentimental escogió el maternal; la nación española era cariñosa, protectora y atenta hacia Cuba. Esta alegoría emotiva cambiaba en las revistas peninsulares y según el mensaje político se representaba un sentimiento u otro; se usaban las emociones como medio de difusión de un discurso político.

El uso del humor tiene relación con la emotividad de las caricaturas analizadas; los estereotipos están cargados de valores emocionales que desprenden y generan durante el proceso comunicativo y en consecuencia «...se puede apreciar cómo en la constante llamada a emociones como la risa se encuentra la clave para detectar los procesos de subjetivación de imágenes en el imaginario colectivo» (Méndez Gómez, 2015, p. 161). El humor en esta ocasión se usó como medio para enviar un mensaje dominante del sistema colonial, utilizado en todos los espacios culturales de la isla. Los discursos políticos de poder se mezclaban con los estereotipos de género y raza para manifestarse en las relaciones alegóricas que representaban a las naciones. La caricatura se utilizó como medio de propaganda cuyo impacto era 
inmediato y marcaba un diálogo con las diferentes ideologías políticas defendidas en cada publicación, el grafismo y su simbología «...se adaptaban a sus necesidades técnicas y sociales» (Bastida de la Calle, 1998, pp. 118-124).

En el fondo del desarrollo de los productos culturales se atisbó una guerra de poder, quien mantenía el control gubernamental tenía las herramientas necesarias para difundir su imaginario nacional. La prensa se convertía en el medio a través del que difundir la idea de la Madre patria bondadosa y sus alegorías nacionales se implantaban en otros objetos identificados con la nación cubana como las marquillas cigarreras. Los colectivos opuestos a este mensaje debían de utilizar otras herramientas para trasmitir su idea de nación u otros circuitos culturales, como el uso de la prensa y los círculos editoriales norteamericanos.

Como último punto reflexivo, he de atender a la trasmisión cultural que partía de occidente y llegó a la perla antillana. Se ha observado como los modelos representativos de España son usados y modificados en la isla, pero hay que dar un paso más y observar como esa iconografía europea será tomada por los movimientos independentistas para generar sus propios imaginarios. Aquí se abre una nueva línea de investigación, que debe ser estudiada y en la que encontramos grandes lagunas, pero no es la única; se debe ahondar en la visión cultural desde abajo buscando nuevas fuentes, que permitan la construcción de esa parte histórica, y analizar las conocidas bajo otra lente. Con ello, se profundizará en la historia cultural dotándola de nuevas perspectivas y se comprenderá mejor esas relaciones entre poder y las transmisiones culturales dentro de las interactuaciones sociales, áreas de estudio interesantes para los investigadores y que tantas preguntas suscitan.

\section{BIBLIOGRAFÍA}

Alaminos López, E. (1999). Representaciones y desarrollo urbano de Madrid hasta 1820. Estampas de Madrid. Vistas de los siglos XVII y XIII (pp. 11-20). Madrid: Museo Municipal de Madrid.

Andreo, J. (2011). La formación de identidades y los imaginarios nacionales de Cuba a inicios del siglo XIX. Procesos: Revista Ecuatoriana de Historia, 34, pp. 37-66.

Anónimo. (1869). Cuba española. Madrid: Imprenta y Librería Universal.

Anónimo. (1873). Cuba y España. Sevilla: El círculo liberal.

Ayala, M. A. (1993). Las colecciones costumbristas (1870-1885). Alicante: Universidad de Alicante. 
Bastida de la Calle, M. D. (1998). La caricatura como forma viva de comentario político: La "Guerra larga» de Cuba (1868-1878) en la revista norteamericana Harper's Weekly. Goya, 263, pp. 118-124.

Berger, P. (1999). Risa redentora: La dimensión cómica de la experiencia humana. Barcelona: Kairós.

Chartier, R. (1992). El mundo como representación. Estudios sobre historia cultural. Barcelona: Guedisa.

De Juan, A. (1983). Imágenes pictóricas de la Cuba del siglo XIX. En J. Puente (Ed.), Pintura española y cubana y litografías y grabados cubanos del siglo XIX (pp. 41-43). Madrid: Ministerio de Cultura, Dirección General de Bellas Artes y Archivos.

Domingo Acebrón, M. D. (1993). Víctor Patricio Landaluze un pintor español masón y anti-independentista en Cuba en la primera mitad del s. XIX. En J. A. Ferrer Benimeli (Ed.), La masonería española entre Europa y América: VI Symposium Internacional de Historia de la Masonería Española (pp. 31-40), Zaragoza: Gobierno de Aragón.

García Ronda, D. (1998). La Habana de Landaluze. En Museo de Bellas Artes de Bilbao (Ed.), Víctor Patricio Landaluze (1830-1889): Colección del Museo Nacional de Bellas Artes de La Habana (pp. 33-47). Bilbao: Museo de Bellas Artes de Bilbao.

Gaskell, I. (1993). La historia de las imágenes. En P. Burke (Ed.), Formas de hacer historia (pp. 209-239). Madrid: Alianza Universidades.

Gaskell, I. (1998). Historia, Historia del Arte y Museos ¿Una conversación a tres bandas? En V. Vázquez de Prada (Ed.), Encrucijada de la Ciencia Histórica Hoy el Auge de la Historia Cultural (pp. 99-109). Pamplona: Ediciones Universidad de Navarra.

Gómez Mompart. J. L. (2010). Metodología para el estudio de la sátira mediática. En E. Bordería Ortiz, F. A. Martínez Gallego, J. L. Gómez Mompart (Eds.), La risa periodística. Teoría, metodología e investigación en comunicación satírica (pp. 39-54). Valencia: Tirant lo Blanch.

Gutierrez, R., Gutiérrez Viñuales, R. (2006). América y España imágenes para una historia. Independencias e identidad 1805-1925. Madrid: Fundación MAPFRE. 
Guzmán Vázquez, D. (2013). La historia cultural como representación y las representaciones de la historia cultural. Cuadernos de Historia cultural, 2, pp. 17-27.

Landes, J. B. (2003). Visualizing the Nation Gender, Representation, and Revolution in Eighteenth-Century France. United States: Cornell University Press.

Lapique Becali, Z. (1999). Los sucesos de la historia de España y Cuba en las etiquetas de los cigarrillos y habanos cubanos. En C. Naranjo Orovio y C. Serrano (Eds.), Imágenes e imaginarios nacionales en el ultramar español (pp. 103-116). Madrid: CSIC-Casa de Velázquez.

Lida, C. E. (2006). Cuba: un desastre anunciado, 1868-1898. Illes i imperis: Estudios de historia de las sociedades en el mundo colonial y post-colonial, 8, pp. 69-82.

López, O. (1998). Víctor Patricio de Landaluze: sus años en Cuba, En Museo de Bellas Artes de Bilbao (Ed.), Víctor Patricio Landaluze (1830-1889): Colección del Museo Nacional de Bellas Artes de La Habana (pp. 9-31). Bilbao: Museo de Bellas Artes de Bilbao.

Méndez Gómez, S. (2015). Feminidades racializadas e imaginarios coloniales en el humor gráfico de Cuba en el s. XIX. IC Revista Científica de Información y Comunicación, 12, pp. 135-170.

Rojas Mix, M. (2005). El imaginario nacional latinoamericano. En F. Colom González (Ed.), Relatos de la nación. La construcción de las identidades nacionales en el mundo hispánico (pp. 1155-1175). Madrid: Iberoamericana.

Pérez Vejo, T. (2005). Imágenes, historia y nación. La construcción de un imaginario histórico en la pintura española del siglo XIX. En F. Colom González (Ed.), Relatos de Nación. La construcción de las identidades nacionales en el mundo hispánico. Vol. II (pp. 1117-1154). Madrid: Iberoamericana.

Pérez Vejo, T. (2009). Representaciones icónicas de la nación en Iberoamérica y España. Arbor. Ciencia, pensamiento y cultura, 740, pp. 1137-1146.

Pérez Vejo, T. (2012). ¿Se puede escribir historia a partir de imágenes? El historiador y las fuentes icónicas. Memoria y sociedad, 32, pp. 17-30.

Cabrera Salort, R. (2010). La mirada de una isla despierta: dos siglos de arte y enseñanza en Cuba. Bordon, 62(2), pp. 93 -106. 
Randazzo Eisemann, F. (2012). Los imaginarios sociales como herramienta. Imagonautas, 2(2), pp. 77-96.

Reyero Hermosilla, C. (2009). El reconocimiento de la nación en la historia. El uso espacio-temporal de pinturas y monumentos en España. Arbor. Ciencia, pensamiento y cultura, 740, pp. 1197-1210.

Rodríguez, O. M. (1998). Landaluze: Pintor de costumbres. Anales del Museo de América, 6, pp. 85-93.

Sánchez Vigil, J. M (2008). Revistas ilustradas en España: del romanticismo a la guerra civil. Gijón: Trea.

Serna, J. y Pons, A. (2005). La historia cultural: autores, obras y lugares. Madrid: Akal.

Villa, R. (1871). El patriotismo español y la insurrección de Cuba: alegoría dramática en un acto y en verso. La Habana: Imp. El Pensamiento.

Zaragoza Bernal, J. M. (2013). Historia de las emociones: una corriente historiográfica en expansión. ASCLEPIO. Revista de Historia de la Medicina y de la Ciencia, 65, pp. 1-10.

Zárate Martin, A. (1992). Pintura de paisaje e imagen de España: un instrumento de análisis geográfico. Espacio, tiempo y forma, Geografía, 7(5), pp. 41-66. 
Página intencionadamente en blanco. 